\title{
The Existence of Women Creating Cakes in Traditional Markets in Supporting The Family Economy and The Survival Strategy
}

\author{
Sumrah A.P \\ STKIP MuhammadiyahBulukumba \\ sumrahpanangrangi@yahoo.co.id
}

\begin{abstract}
This research is conducted in the traditional market of Bulukumba using quantitative descriptive method aiming to study the existence of women selling pastry in the traditional market to supportfamily economy and survival strategy. The research subjects are women selling traditional cake in Bulukumba. The result of the research shows that the role of women as cake sellers in supporting relative in large family economy and survival strategy is done by establishing the pattern of relationship to the neighborhood, owed to fulfill the needs of the nearest shop, and minimize the expenditure of low as possible may be very important.
\end{abstract}

Keywords: women, traditional market, family economy, and survival strategies

\section{INTRODUCTION}

Women's role in economic activity is a phenomenon that is often found in society, especially in lower middle economic society. Economic difficulties force women from low economic class to take a role in increasing their family income by working outside the domestic sector.

Economic conditions has encouraged women to take part in economic activities, one alternative that can be done is to sell pastry at traditional markets, because this work is relatively easy to do. The phenomenon can be seen in many places. The reason women selling cakes in Bulukumba traditional market is to meet the family needs.

The above description shows that women will never sit still facing economic difficulties, nevertheless, they always try to ease the burden of household, soas to meet the needs of the household. Such phenomenon suggests that working women are not solely for leisure or career development, but rather to provide more earnings for the family mainly because her husband income is not that sufficient to meet the needs.

Women are individuals that deserve great attention considering that one third of the world's population lives below the poverty line, about 70 percent of women. In This is one factor related to the ability of a person to be active in economic activity, while the results showed that 42.2 percent of respondents aged between 40-49 years, 37.8 percent aged between $30-39$ years, then 15.6 percent who are less than 30 years old, and 4.4 percent who aged
Indonesia, number of the poor reaches 31.02 million people, 70 percent of them are women (BPS, 2011).

Based on the above description, it is very interesting for writers to examine the existence of women selling pastry in traditional markets Bulukumba as one of the strategies to increase family income and survival strategy.

\section{METHOD}

This research is conducted in a field research in traditional market of Bulukumba. It is descriptive research with the basis of survey research, it reviews a case that investigate phenomenon in real life context. This research is a micro sociology study, which seeks to understand social reality of household life of women as cake seller in the traditional market. The analytical descriptive approach as confirmed by J. Vreden bergt, aims to describe complex social reality by applying concepts that have been developed by social scientists [1].

In this study, social reality studied is household social life in the family of women selling pastry in Bulukumba traditional market sunder the issue of the existence of women selling pastry in traditional markets to support the family economy and survival strategy as much as 45 respondents.

\section{RESULT}

The data in this study are presented descriptively and quantitatively. Here are the data.

Someone's level of education is highly related to productivity, and will affect level of person's income. Based on data collected from respondents in the study area, it indicates that most of them are those who do not go to school for 53.3 percent, who did elementary education for 35.6 percent, who did junior high school for 6,7, high school for 2.2 percent, college education for 2.2 percent. The data showed that in general they were not in school and had low education. Low education could lead to a person's incompetency and limited experience to a simple experience.

50 years and over. The data shows that in general the age of the respondents is still classified as productive age. Number of children

The number of children owned relates to family expenditure. The number of children owned by respondents is generally $2-3$ people, that is 37.8 percent, 
less than 2 people as much as 28.9 percent, 4-5 children as much as 22.2 percent, and over than 5 children only 11.1 percent. This shows that respondents in the research area have adopted Family Planning program so that most of them have children between 2-3 people.

Respondents' Revenue

The respondent's income is income earned from the cake selling. Apparently, 42.2 percent of respondents earned between IDR 750,000 - IDR 1000,000 per month, 35.6 percent of the income>IDR 1000,000, 15.5 percent who earned between IDR 500,000 - IDR 749,000, and 6.7 percent who earned <IDR 500,000 per month. Looking at the data, it can be said that the income of respondents to support the family economy is not small amount because most of them earn IDR 750,000 to top per month.

Husband work

Type of work is closely related to someone's income. Husband's working typerecorded as follows. The ones who work as farmers as much as 42.2 percent, as fishermen and laborers each 20 percent, pensioners for 4 percent, and the rest are 4 percent who do not have permanent job. Those aforementioned working type generally does not require a certain skill or level of education, and such conditions will be related to someone's income.

Husband's Respondent's Revenue

The income of the husband as respondents varies. The data on the husband's income per month shows that 57.8 percent of the income is IDR 1000,000 - IDR 1,500,000, 20.0 percent for >IDR. 1.500.000, 17.8 percent for IDR 500,000 - IDR 999,000, and the remaining 4.4 percent for $<$ IDR. 500,000. The data shows that only 20 percent of the income>IDR $1,500,000$ and the most high are the income between IDR 1,000,000 IDR $1,500,000$ as much as 57.8 percent.

Women's Role of Cake Traders in Traditional Market to Support Family Economy

Women's involvement in economic activity to improve family economy is done in various fields both formal and in formal sector. As it appears in the research area that respondents engage in economic activity every day by selling cake in traditional markets to support family income.

\begin{tabular}{|c|l|c|c|}
\hline 4 & $<$ IDR. 500.000 & 3 & 6,7 \\
\hline \multicolumn{2}{|c|}{ Total } & 45 & 100 \\
\hline
\end{tabular}

It is recorded that cake selling per month are >IDR $1,000,000$ for 35.6 percent; IDR 750,000 - IDR 1000,000 for 42.2 percent; IDR 500,000 - IDR 749,000 for 15.5; and the ones who earn <IDR 500,000 only for 6.7 percent. The amount of earnings is used to purchase the daily needs and pay school fees of their children. According to the women as respondents of

Strategy to Survive of Women Cake Sellerin TraditionalMarket

Every household will always try to survive with other family members through various strategies. A strategy is a way gone through by family to continue living their life. The low-income family finds it hard to
[2] suggests that, one of the goals of a person working is to earn money. This has encouraged women to support the household economy becomes very important and participate in the economic sector to increase the family's income to meet the needs,

The income of the husband can be seen in table 1

Table 1. Distribution Husband's Revenue

\begin{tabular}{|c|c|c|c|}
\hline No & Revenue permonth & F & Persen \\
\hline 1 & $>$ IDR 1,500,000 & 9 & 20,0 \\
\hline 2 & $\begin{array}{c}\text { IDR 1,000,000 - } \\
\text { IDR 1,500,000, }\end{array}$ & 26 & 57.8 \\
\hline 3 & $\begin{array}{c}\text { IDR 500,000- IDR } \\
999,000\end{array}$ & 8 & 17,8 \\
\hline 4 & $<$ IDR 500,000 & 2 & 4,4 \\
\hline \multicolumn{2}{|c|}{ Total } & 45 & 100 \\
\hline
\end{tabular}

Considering on the amount of income of husband in research area at table 1,it can be said that the income is still very low compared to UMR (Regional Minimum Wage) in South Sulawesi in 2017 amounted to IDR 2,647,767 / per month, as well as the price of basic necessities that are increasing, so that with such amount of income will cause the inability to meet the daily needs.Therefore, they face difficulty to live the family life.

[3] in his study of the Circular Migrant Survival Strategy in Makassar city suggests that the role of wives and other family members helping the household income is very large. If only relying on their husbands' income, the wives feel it hard to survive in the present condition while all daily necessities are expensive.

This economic burden imposes the women on making money, as their role is pivotal to keep the family daily needs fulfilled. This can be seen in table 2 .

Table2. Distribution ofRespondents' Revenue permonth

\begin{tabular}{|c|c|c|c|}
\hline No & Revenue permonth & F & Persen \\
\hline 1 & $>$ IDR. 1000.000 & 16 & 35,6 \\
\hline 2 & $\begin{array}{c}\text { IDR. 750.000 - } \\
\text { IDR. 1000.000 }\end{array}$ & 19 & 42.2 \\
\hline 3 & $\begin{array}{c}\text { IDR.500.000- } \\
\text { IDR. 749.000 }\end{array}$ & 7 & 15,5 \\
\hline
\end{tabular}

this research, if only relying on their husbands' income with the current economic condition, the life necessities will not be fulfilled. Therefore, they work hand in hand with their husbands even though they must get up early for selling preparation.

survive, but without such effort, managing life with low income is very difficult.

One strategy that is done is through the Kinship Network; it is a form of family relationships in social life. This is one of the social potentials which is rich of socio-cultural values exists in the community. These socio-cultural values can encourage the helpless family 
or give mutual help among peoplein overcoming the problems faced.

[4] suggests that the choice of suburban community life strategy is closely related to the value system that lives in the community; whether it is local power (kinship) or social solidarity. Social solidarity with kinship and kinship ties, and customary ties tend to contribute to variations in the form of survival strategies.

One strategy that is done to keep them alive is to make efforts to build a good relationship with neighbors or with other families, where in this case it appears that they give and take help from others. Such things can be seen when the neighbors need help so they spend time to help, this can be done when they come home from the market. According to the respondents, to help others they sharetheir time and energy. Also, when the selling cake does not run out, they will share them to the neighbor.

Apparently, in relation to the utilization of social networks, respondents use neighboring services as a place to borrow when their supplies are out of stock to meet the necessities of life. In addition, they can file a loan in neighboring stalls; such things are understood as symbol of solidarity as neighbors and also a family. Other than being active in economic activities, the women also make some adjustment to their living condition. When the income exceeds the expenditure, they have to reduce some amount of household expenditure by addressing the necessities of life. Also, they try to have saving even with relatively small income. According to the respondents, saving is an effort made to reduce some expenditure to a minimum to keep them alive.

[5] suggests that the low economic condition of a family has encouraged society to develop an economic strategy that includes allocation of resources, especially labor in both sectors of production and non-production. Efforts in the production sector point to the various activities of household members in the field of production economics. Meanwhile, the efforts of the non-production sector point to the involvement of the members of the household in various social welfare institutions in the society.

The role of women in the economic activities is one form of adjustment patterns undertaken by poor households in the research area which is life demanding in which they have to work (they have to work) not choose to work (they choose to work).

\section{CONCLUSION}

The role of women selling pastry in traditional markets is relatively large in order to support the family economy and to survive, and the strategy undertaken is not only limited to raising family incomes but also building good relationships with neighbors or other families.Suchthing can be seen when neighbors are in need of help they spend time helping out, and also respondents will need their neighbors to borrow something when their basic needs are out of stock. Another strategy used to manage the household finance is by trying to save on expenses even with relatively small income.

\section{REFERENCES.}

[1.] Vreden bergt, J. Metode dan Teknik Penelitian Masyarakat. PT. Gramedia, Jakarta.1979.

[2.] Indri watigunawan. Wanita di sektor informal dalamPrisma x jakarta LP3es. 1992.

[3.] Malik, S. Startegi Kelangsungan Hidup Migran

[4.] Sikuler di Kota Makassar. UGM. 2000.

[5.] Suharso,P. Tanah, Petani, PolitikPedesaan. PondokEdukasi. Solo.2002.

[6.] Sitorus.M.T.Felix,.Strategi Ekonomi Rumah Tangga Nelayan Miskin. Yayasan Obor, Jakarta.1999 